Public opinion on energy crops in the landscape: Considerations for the expansion of renewable energy from biomass

Trudie Dockerty*, Katy Appleton, Andrew Lovett

School of Environmental Sciences, University of East Anglia, Norwich, NR4 7TJ, United Kingdom

*t.dockerty@uea.ac.uk 


\section{Public opinion on energy crops in the landscape: Considerations for the expansion of renewable energy from biomass}

Public attitudes were assessed towards two dedicated biomass crops - Miscanthus and Short Rotation Coppice (SRC), particularly regarding their visual impacts in the landscape. Results are based on responses to photographic and computer-generated images as the crops are still relatively scarce in the landscape. A questionnaire survey indicated little public concern about potential landscape aesthetics but more concern about attendant built infrastructure. Focus group meetings and interviews indicated support for biomass end uses that bring direct benefits to local communities. Questions arise as to how well the imagery used was able to portray the true nature of these tall, dense, perennial plants but based on the responses obtained and given the caveat that there was limited personal experience of the crops, it appears unlikely that wide-scale planting of biomass crops will give rise to substantial public concern in relation to their visual impact in the landscape.

Keywords: public attitudes; biomass crops; visual landscape impacts; landscape visualisation

\section{Introduction}

Renewable energy produced by processing and burning perennial biomass crops such as Short Rotation Coppice Willow (SRC) and Miscanthus grass has been identified as one of a range of measures to meet national and international targets for reduced greenhouse gas emissions (Royal Commission on Environmental Pollution 2004; UN Energy 2007; HM Government 2009). In 2007 the UK Biomass Strategy estimated that there was up to 15,500 ha of SRC and Miscanthus planted in the country with the potential for the area of perennial energy crops to expand to 350,000 ha by 2020 (Defra, DTI and DfT 2007). This would translate to planting on around $10 \%$ of arable land in some regions. However, the cultivation cycle for SRC and Miscanthus is different to most current rural land uses; the rootstock is in place for 7-25 years, harvest is normally in early spring (February-March), annually for Miscanthus and approximately every third year for SRC. When mature these crops are dense and tall (3-5 m), and they may also be planted in large blocks for practical reasons relating to cultivation and harvesting. If the overall area of these crops is to be greatly expanded, there is clearly potential to modify the rural landscape, with particular implications for visual appearance, and thereby cultural heritage and tourism, as well as farm incomes, 
hydrology and biodiversity (Upreti 2004, Rowe et al. 2009, Haughton et al. 2009). Concerns about these crops' potential impact have also been expressed by various wildlife and rural NGOs (Wildlife and Countryside Link 2007).

Such issues are of interest to a range of government agencies and NGOs, and this has stimulated discussion regarding the development of planning policies and tools to maximise the benefits of planting and minimise adverse effects (e.g. English Heritage 2006, Defra 2004, 2007). As with other choices of agricultural crop, planning permission is not required for the planting of Miscanthus or SRC, but in most cases some restrictions and guidelines will be applicable under Defra's Energy Crops Scheme (Natural England 2009), without whose support these crops are not usually economically viable. Few of these specifically relate to landscape, but a site visit is required which considers, among other factors, the "impact of proposed plantings on surrounding landscape and land use". Applicants are directed to the Code of Good Agricultural Practice (CoGAP) (Defra 2009), which refers to maintaining and improving the landscape and respecting the public's appreciation of the countryside, and states that Common Agricultural Policy cross compliance measures should be followed. In turn, the cross compliance guidance for Maintenance of Habitats and Landscape Features (Rural Payments Agency \& Defra 2007) contains some Good Agricultural and Environmental Conditions (GAECs) relating to landscape elements, such as hedgerows, trees and stone walls, but large-scale landscape patterns and character are not explicitly considered. More detailed landscape-related guidance exists for SRC as a form of forestry, both specifically (Forestry Commission 2001) and generally (Forestry Commission 1992), but this has not been explicitly extended to Miscanthus. While there is therefore acknowledgement that biomass crops have the potential to cause adverse changes to 
landscape character, the actual guidance available is somewhat vague, reflecting the fact that the public's opinion on the crops' appearance, and the effects of this on the acceptability of biomass energy in general, have not been explored.

There have been various approaches to landscape assessment over the years (Swanwick et al. 2007). The more holistic approach of current Landscape Character Assessment methods has evolved from more quantitative approaches based on measuring and evaluating individual landscape elements, and attempts to look at both landscape components and the way in which they interact to create the landscape as a whole. It is therefore possible to examine the documented landscape character of an area and determine which elements may be affected by changes such as the introduction of biomass crops, how significant those effects might be, and whether there are ways in which any negative implications could be ameliorated or avoided. This has been done as part of a Sustainability Appraisal (SA) within the RELU Biomass project (publication in preparation), with the conclusion that while there is potential for serious landscape impacts in some more sensitive areas, it should be possible to implement biomass energy schemes, particularly with smaller overall amounts of planting within a region, without significant deterioration of landscape character and quality as currently assessed. It is recognised, however, that this may not equate to public acceptability and so the survey and focus group element of the work, reported here, form an initial investigation of the issue.

The overall public acceptability of biomass energy may also be affected by a lack of general understanding. Previous studies in the UK have found that there is a poor public understanding of terms such as 'renewable energy' or 'biomass'. For instance, a MORI (2004) poll for Regen SW of 218 residents of Devon found that 52 $\%$ had never heard of biomass power. The DTI (2003a, 2003b) funded two studies, 
each with a considerable sample size, to assess knowledge and awareness. Both found low awareness of 'renewable energy' in their samples and even less understanding of the term 'biomass'. The first study (DTI 2003a) found that even people living in proximity to biomass plants were unfamiliar with the term and suggested that participants found it difficult to distinguish between biomass and incineration. More generally, for any renewable energy technology there was a strong tendency for greater knowledge of it to be associated with greater acceptance. Solar power was rated highest of nine generation technologies on both of these scales, while biomass was placed lowest in each case (DTI 2003a, p.44).

Finally it is important to remember that biomass energy relies on both crops and infrastructure; a range of generation options exist including local scale combined heat and power (CHP), dedicated biomass power plants, and co-firing in conventional coal power stations. Transport infrastructure is also needed to carry crops to where they will be burned. Several proposals to construct biomass power plants have attracted strong local opposition (Upreti 2004, Upham and Shackley 2006, DevineWright 2007) with infrastructure considerations, including transport, greatly overshadowing any potential landscape impacts from associated crops in terms of public opinion. Perhaps for this reason, little work has been done to assess the wider landscape issues, but given the potentially widespread planting of crops such issues of public acceptability will clearly be important if energy generation from crops such as SRC and Miscanthus is to become more common in the UK.

\section{Aims}

This research was undertaken as part of the RELU-Biomass project (http://www.relubiomass.org.uk) which ran from 2006 - 2009 and aimed to provide an integrated 
assessment of the potential impacts of increasing rural land use under biomass crops at spatial scales ranging from the site to the region. Other work undertaken within RELU-Biomass included measurements of water use and biodiversity in fields of the crops and farm surveys. The results are being used to develop an integrated framework for a Sustainability Appraisal (SA) of conversion of land to perennial energy crops and to provide input into best practice guidance for planting of SRC and Miscanthus. RELU-Biomass focused on two contrasting regions of the UK where SRC and Miscanthus are currently being grown - the East Midlands and South West.

The SA involved stakeholders in both study regions, who set the objectives and indicators used to assess sustainability for a set of theoretical 'scenarios' concerning various degrees of expansion in the planting of biomass crops. These scenarios are listed in Table 1 and form the basis for a number of the visualisations produced and used in this assessment of public attitudes.

This analysis of public attitudes focuses on the visual impacts of the crops in the landscape, with reference to the above-mentioned scenarios. Specific aims were

- To assess awareness of and attitudes towards the crops,

- To assess the level of planting (landscape change) that would be acceptable,

- To assess preferences for the distribution of the crops in the landscape and at field scale,

- To assess views on the different forms of infrastructure associated with processing and preferences regarding utilisation of the crops for fuel. The analysis is based upon a public questionnaire survey, focus group meetings with community groups, insights from stakeholder meetings, and interviews with key industry and local government officers. In total the views of over 550 people contribute to the findings. 


\section{Method}

A range of photographs and computer-generated images were used to try and depict the nature of the crops and how they differ from conventional agricultural land uses. The main reason for using this imagery was that previous studies (e.g. DTI 2003a) suggested that it was likely that only a small proportion of the general public would be aware of SRC or Miscanthus.

Furthermore, research has shown that information presented in a visual form offers great potential for facilitating stakeholder participation in decision-making processes (Bishop and Lange 2005, Jude et al. 2006, Miller et al. 2008).

Developments in computer software and graphics capabilities mean that it is now possible to generate static images and real-time models (so-called because the user can change their viewpoint at will) representing real and geographically accurate places and portray them as they are now, as they were in the past, or as they might be in the future. One use of such visualisations is to depict 'scenarios' that portray the various possible outcomes of future policy options, acting as a focus to help stakeholders and decision makers better understand and evaluate the potential consequences of policy choices.

The questionnaire survey, interviews and focus group meetings described in the following sections were all designed to elicit views that would enable us to evaluate the public acceptability of the various elements of these scenarios and help inform the SA.

The questionnaire survey included photographs of the crops in various settings for people to comment on. For the focus group meetings and interviews, a number of different visualisations were produced, including panoramic photographs of the crops 
at different times of year (Figure 1), a GIS-based 'real-time' landscape model showing Miscanthus planting for an area in the East Midlands, and computer generated still images views representing airborne views of different planting scenarios and ground level illustrations of different field margin widths for both Miscanthus and SRC in the East Midlands. Further discussion of this imagery can be found in Section 4.

\section{Questionnaire survey}

The questionnaire survey took place in town centres within the East Midlands and South West where SRC and Miscanthus are grown in the surrounding areas. The particular objectives of this work were to:

- Compare knowledge and attitudes regarding different methods of energy generation in these localities with previous results from national surveys

- Assess the extent of public awareness of biomass crop planting in the surrounding areas and attitudes towards the visual appearance of SRC and Miscanthus

- Examine whether attitudes towards the crops changed when a link with the presence of a nearby biomass power station was made more explicit.

The questionnaire (Table 2) included certain questions that had been asked in a national 2005 UEA/MORI survey on energy options in Britain (MORI 2005, Poortinga et al. 2006) in order to allow a comparison with that study. The survey was designed to be conducted in the street and therefore needed to take no more than about five minutes. Several questions relied on of photographs of SRC and Miscanthus close-up and in a landscape setting, and also of a biomass power station. 
A target was set to survey a cross-section of 100 local respondents in each urban centre, with efforts being made to reach target numbers of survey respondents in eight age/gender categories. As well as the questions on biomass energy, some demographic information was requested, and 'energy awareness' was established via a question on respondents' use of energy efficient light bulbs at home.

\section{Focus groups and interviews}

The reason for holding focus group meetings and interviews was to obtain more in-depth responses than were possible in the necessarily brief street survey. The original aim was to hold the focus group meetings in rural areas where it was more likely that local people had some experience of the crops, identified via applications for planting grants through the Energy Crop Scheme (Natural England 2009).

However, many of the approved planting grants were never taken up as farmers chose instead to take advantage of record prices for wheat in 2007 (BBC 2007). This made it much more difficult to identify suitable study areas in the way originally envisaged. In addition to high wheat prices, the focus group exercise also took place during a time where oil prices reached record highs, with economic knockon effects forcing food shortages in some parts of the developing world and a general questioning of the sustainability of using crops and land for fuel production giving rise to considerable heated 'food versus fuel' debate in the press (Monbiot 2007, Johnston 2010). The sensitivity of this issue drove a switch to more general meetings and interviews not linked to specific locations that might prove inflammatory, but which would still add to overall understanding regarding the public acceptability of biomass crops in the landscape. 
Interviewees and focus group participants were identified through contacts in local government and other relevant agencies. Meetings were instigated with representatives of five organisations with an interest in biomass crops and landscape in the East Midlands and six organisations (including two community groups) in the South West. The number of people interviewed or entering into discussion via focus groups totalled 11 in the East Midlands and 44 in the South West.

Attendees of the meetings were shown a presentation introducing the project, including the same images of the biomass crops used in the street-based questionnaire survey that took place the previous summer. They were asked similar questions about the acceptability of the crops in these settings. In addition to these photographs, interview and focus group participants were shown 'bird's eye' computer-generated visualisations of landscapes within the relevant region depicting different scales and distributions of biomass crops to try to convey the landscape change that would be brought about by increased areas of planting. Examples are shown in Figure 2. These images were accompanied by maps showing a plan view of each planting scheme.

Participants were also shown visualisations along a public footpath and further ground-level images representing the impact of changing field margin widths as might possibly occur under future agri-environment schemes. Figure 3 shows an example for SRC planting.

Photographs and descriptions of the infrastructure associated with different potential end uses for the biomass crops (co-firing in coal fired power stations; dedicated biomass power stations, and small-scale biomass boiler units) were also shown and in each region a local example was presented showing the land-take needed to produce sufficient crop yield to supply a power station capable of meeting the needs of the local community (see example in Figure 4). These latter results were 
based on analysis in Lovett et al. (2009b), a GIS-based constraints mapping exercise to identify suitable land for growing Miscanthus.

\section{Results}

\section{Questionnaire survey}

In total, 490 complete questionnaires were obtained, exceeding our target of 100 respondents from each location.

Perhaps unsurprisingly for a day-time street-based survey, our respondents included a slightly higher proportion of non-working people than are represented in the general population and a lower proportion of working people. Overall, the data represents reasonable cross-section of the population in each location based on comparison with overall UK population figures for the age categories used.

In the presentation of results that follows such variations are only mentioned when the chi-square test indicated a difference in responses that was statistically significant at the $95 \%$ confidence level.

\section{Opinions and awareness of energy sources}

Table 3 shows the level of approval for each source of electricity generation across all locations. It indicates a high level of support for biomass and other renewable fuels. Those people who knew biomass is renewable were mostly likely to strongly or slightly approve of using it as a fuel, whereas respondents who thought it was not renewable were most likely to be opposed to using it.

Contrary to earlier studies (e.g. DTI 2003a, 2003b) the great majority of respondents were able to correctly differentiate between renewable and nonrenewable fuel sources. Sun/solar, tidal, wind and hydroelectric power were each 
correctly identified as renewable by at least $88 \%$ of respondents, and fossil fuel options were stated as non-renewable by at least $75 \%$ of people. Biomass energy was only slightly lower with $68 \%$ correctly identifying it as renewable, while nuclear power saw $28 \%$ thinking it renewable, $46 \%$ non-renewable, and $26 \%$ saying they didn't know - the largest undecided proportion in all of the choices presented.

The factors that people selected as most important for deciding which methods of electricity production should be used in Britain in the future are summarised in Table 4. Findings from the 2005 UEA/MORI survey are also given for comparison. Participants were asked to select and prioritise three factors from a list of nine. Effect on the environment was the most selected factor. This was followed by effects on health, helping to prevent climate change and then cost to the consumer. Impact on the landscape was the least mentioned of the nine specific factors. However, in terms of priorities, cost was mentioned more often than effects on health or climate change prevention.

\section{Public Responses to SRC and Miscanthus}

Awareness of Short Rotation Coppice or Miscanthus being grown in the areas around the survey locations was generally low. The majority of people questioned were not aware of either crop growing in the vicinity, although more had noticed SRC (32.2\%) than Miscanthus (17.6\%). A significantly higher than expected number of people living in Retford had seen SRC, and similarly more respondents in Taunton were aware of Miscanthus in the area, reflecting regional differences in the relative abundances of the crops. Whether a crop had been previously noticed or not had no statistically significant influence on general approval of biomass as an energy source in responses to Question 1 in the survey. There were some differences in responses 
depending on whether people had noticed the crops growing locally. Those who had noticed SRC were significantly more likely to say that it fitted into the landscape very well. A similar trend was apparent for Miscanthus, but the difference in response was not statistically significant.

Table 5 indicates that when shown pictures of the biomass crops in landscape settings, most people thought that they would fit into the local landscape very well or reasonably well. (SRC $86.7 \%$ : Miscanthus $75.1 \%$ ). Those who were in favour of biomass for electricity production and those classed as 'energy aware' were most approving.

Respondents were presented with views (Figure 1) of energy crops in the landscape and asked to specify where, in relation to their home and in terms of increasing distance away, they would accept the crops being grown. The majority of respondents said they would not mind seeing SRC and Miscanthus (68.2\% and 64.9 $\%$ respectively), within the view from their home, with another $19.6 \%$ (SRC) and $20.4 \%$ (Miscanthus) approving of the crops being visible on the outskirts of their town or village. Again, approval was greatest from those who supported biomass as an energy source. It should be acknowledged that "within the view" was not at a specified distance, and so effectively would have related to the distance of the crop from the viewpoint in the images shown.

Respondents were asked if they had a favourite local walk, and those that did (70.4\% of survey participants) were asked to picture SRC and Miscanthus in its vicinity. Again, the majority (and particularly biomass supporters) said they would not mind if SRC or Miscanthus were grown alongside the footpath (60.4\%; $56.0 \%)$ or within the view $(31.3 \% ; 33.7 \%)$. 


\section{Responses to Power Generation Infrastructure}

Following presentation of a photograph showing a biomass power station (Figure 5) and explanation that for economic reasons biomass would need to be processed and utilised within about a 25 mile radius of where the crops are grown, respondents were again asked how close to their homes they would mind if SRC and Miscanthus were grown. Figure 6 illustrates the distribution of responses before and after presentation of the power station view. Rather fewer people were willing to have SRC and Miscanthus within the view from their home $(27.4 \% ; 28.3 \%)$, with shifts towards the other categories becoming more pronounced with distance. Those that thought that the crops should be grown more than 10 miles away from their homes increased from 4.1 $\%$ to $24.8 \%$ for SRC and $4.9 \%$ to $25.8 \%$ for Miscanthus. Over $45 \%$ of those who originally said they wouldn't mind biomass crops within the view of their home were in the highest 'energy awareness' class, but even these people exhibited a similar degree of negative response towards power generation infrastructure, as did those who (strongly or slightly) supported biomass as an energy source. It should be made clear that the questionnaire asked for opinions only on the cultivation of crops, and not on placement of generation infrastructure.

\section{Findings from focus group meetings and interviews}

Tables 6 and 7 summarise the key issues encountered during the discussions, listing concerns raised in relation to each crop, example comments, and preferences in relation to planting scenarios, field margin width and method of power generation. The values are the number of times each issue was mentioned; only a single time in the majority of cases. In general, most people appeared to have very little to say on 
the issue, reflecting perhaps, limited exposure to and knowledge of the crops (as found in the questionnaire survey).

Although Miscanthus produced a much wider range of concerns than SRC (26 issues raised with a total of 46 mentions), it should be noted that we spoke to more people about this crop due to higher response rates in the South West. Only four concerns were raised about SRC, and three of these were also among the most often mentioned in relation to the production of Miscanthus: increased lorry movements, loss of view and the 'food versus fuel' land-take issue. The sole benefit mentioned in relation to SRC in the East Midlands was that it might enhance landscape and this was also raised with regard to Miscanthus in the South West. Given these results, although the individual crops are referred to in the following discussion it is not generally intended to imply that the findings apply only to one crop and not the other.

The one example of a crop-specific issue came from the South West (where the focus of our study had been on increased planting of Miscanthus as an energy crop); the most frequently raised issue was why Miscanthus was being considered as a crop for this area, when Somerset had a historical link with willow production (formerly for basket making, fencing etc). It was suggested that SRC might be more appropriate or that local focus should be on utilising existing wood fuel through better woodland management. This was suggested as having little or no implications for landscape change, whereas the conspicuousness of Miscanthus in the landscape was mentioned by a moderate number of people.

In terms of landscape management, dispersed or random planting patterns of small fields were preferred to planting in large blocks of adjacent fields. The $10 \mathrm{~m}$ field margin received the highest voiced support (mostly in relation to possible biodiversity benefits), though there were some who thought that margins were 
unnecessary - "If you've lost the long view it doesn't matter much about the width of the margin" - and other comments that wide margins next to roads might be a hazard for wildlife or encourage unwanted trespass.

Few non-landscape issues were raised, but given the context of the focus groups this is perhaps not surprising. There was some concern that long-term cultivation of Miscanthus would lead to a reduction in soil fertility, although there appears to be little clear supporting evidence for this assertion for either crop, and the team noted that the point was not made by farmers or land managers. And only once were comments made about the potential contribution of energy crops to renewable energy targets, with one person saying “The landscape issues shouldn't get in the way of the positive renewable energy aspects".

In terms of end use, of the few views expressed, most were in favour of smallscale boilers and CHP units. One participant said "In the East Midlands co-firing will prevail but there is a lot of interest in small scale boilers for schools and communities". Another said "people will like the idea of crops grown locally being used locally". However, a more sceptical view from the South West was "If it's expensive to install and not a lot cheaper to run we wouldn't want it. It wouldn't be worth ruining the landscape for".

\section{Discussion}

The questionnaire responses relating to energy sources were intended to provide a context for respondents' answers, and some responses do vary according to these factors. It is encouraging to note that understanding and approval of biomass energy have increased slightly since the previous UEA/MORI poll, although more traditional renewable technologies remain more familiar. General support for the cultivation of 
biomass crops as a source of energy was diminished when the question of power generation infrastructure was included, even among those who were more energy aware and supportive of renewable technologies. This supports the observation from previous literature that these parts of any biomass scheme will be the most contentious in terms of public acceptability.

There was very little difference in support for SRC compared to Miscanthus, aside from the cultural heritage factor in the South West, and no significant differences in attitudes to the crops between people from different regions. For the purposes of the remainder of this paper, attitudes towards biomass energy crops will be considered without differentiation as to plant species or region.

The overwhelming positive response of those who said they would not mind if biomass crops were grown within sight of or alongside their favourite local walk was felt to be somewhat surprising by the research team, whose experience with biomass crops was limited prior to this project and who therefore had recent personal experience of encountering them for the first time at their full height and density. This raises some concerns that, from the visual material supplied, respondents may not have fully appreciated the visual impact these tall and densely grown crops can have at ground level, particularly since relatively few people reported direct experience of either crop. At first glance this statement would also seem to contradict with the finding that survey respondents who had seen SRC growing locally were more positive about its presence in the landscape than those who had not; however, acceptability in the wider landscape (at medium to long distance) is not incompatible with having negative impacts at very close quarters. Furthermore, the focus groups and interviews (where there was more time for discussion and exploration of the images) brought more mentions of "losing the view" than any other benefit or 
drawback, indicating that this is potentially a significant concern. The use of short surveys and visualisations in this piece of research are discussed further below.

Similar limitations could also have influenced the initially strong level of support for growing SRC or Miscanthus within view of home or on the outskirts of respondents' villages or towns. This contrasts strikingly with the response after seeing the power-generating infrastructure that could accompany the crops, which saw a distinct shift in preference towards planting in more distant locations, even from those who strongly approved of biomass as an energy source. We did not have the opportunity in the questionnaire to examine responses to small-scale, more localised combined heat/power plants such as farm-scale generating units. This was therefore made one priority of the follow-up interviews and focus group meetings, where there was generally more support for smaller, local-scale options.

Many of the issues raised in the interviews and meetings (Tables 6 and 7) coincided with those identified by expert stakeholders in the development of the Sustainability Appraisal (Table 8). This gives some confidence that, despite the small sample sizes that we were able to obtain, the discussions did cover the most important issues at least briefly. Overall, compared to the questionnaire, the meetings offered valuable additional insights into attitudes towards the two crops under study, but did raise one interesting contrast. Two most commonly mentioned concerns (loss of view and conspicuousness in the landscape) appear to contradict the findings of the questionnaire where respondents were generally unconcerned about the presence of biomass crops in the countryside. This is perhaps due to the different amount of time and consideration given to the crops by the two sets of participants; Swanwick et al. (2007) note that quantitative landscape survey techniques using quick, one-off surveys can give misleading results as people "have often not thought deeply about 
such issues and need time to reflect on their values and preferences, and to understand the nature and significance of the issues at stake" (Swanwick et al. 2007, p. 20). It is certainly something which requires further investigation.

Otherwise, although a considerable number of concerns were raised, these were generally only by one, or at most a few, individuals, indicating no strong majority objection on any issue. Only a few people chose to express a preference on planting scenarios, margin widths or end uses; although there was some support for distributed planting and wide field margins, it was not overwhelming. Again, this may be due to lack of personal experience of the crops, some deficiency in the information provided, or an indication that it was really of no great importance or interest to most participants (a possibility which is reinforced by the low participation rate in the East Midlands).

The use of image-based information is necessary within a short street survey as used here. We took considerable care over the selection of images used in the survey (e.g. including views with people or vehicles to give a sense of scale), but it was difficult to evaluate whether respondents could accurately assess the potential impact of these crops on the landscape from the views presented. Previous work has been done to attempt to validate the use of photographs and computer-generated images as environmental surrogates in landscape evaluation, and while meta-analysis has supported their use (Palmer and Hoffman 2001), several studies have suggested that factors such as non-visual stimuli, dynamic landscape elements, panoramic views and sequential exposure to views as part of an activity such as walking may all lead to differences between on-site and image-based assessment of landscapes (Stewart et al. 1984, Hull and Stewart 1992, Daniel and Meitner 2001), and all of these are potentially relevant to the experience of biomass crops in the UK landscape. 
It is clearly important to consider how image-based surrogates may mimic the respondent's likely interaction with the landscape; in this case, with the sample groups used, it is possible that many respondents would experience the landscape passively and at some distance, perhaps from a car and therefore images may be sufficiently valid surrogates (Hull and Stewart 1992, Daniel and Meitner 2001). However, there is scope for more comprehensive work in future given that there are features of biomass crops that are significant at close quarters, such as their size and density, noise effects (screening of other noise sources such as roads, and white noise generation) (Dwyer et al. 1991, Dockerty et al. 2008) and effects on wildlife (such as greater numbers of butterflies) (Haughton et al. 2009). These could be particularly important for residents living very near proposed plantings and for recreational users of the affected areas. Furthermore, beyond the use of still, photograph-like images there are further questions relating to the validity of computer-generated visualisations. Overall, there remains a need for examination of modern computer graphics of all kinds as valid representations of the real world (Wergles and Muhar 2009), particularly when representing dynamic, organic elements such as biomass crops.

Landscape preference is not a simple thing to define or predict, and therefore nor are the more general (and subtle) potential effects from novel crops, that may not be apparent at first glance. For example, returning to the fundamentals such as Appleton's (1996) prospect-refuge and habitat theory, there are clearly ways in which the introduction of tall, dense crops could alter the balance of basic elements within the landscape and therefore make it more or less attractive. Furthermore, landscape in its widest sense is inextricably bound up with personal and place identity, that is, how people see themselves and where they belong. This can be threatened, for example by 
the imposition of change by outside agencies, such as was perceived in some of the previous examples of public objection to biomass schemes (Devine-Wright 2009). There are clearly more complex factors and processes at work to determine public acceptability than the simple question of whether a particular landscape is instantly visually attractive.

In terms of the experience gained in using visualisations during this research it became apparent that there were advantages in using a mixture of display types. Realtime models proved very effective as an engagement or demonstration tool, but sequences of rendered still images were a more straightforward way of depicting sets of scenarios or before/after views. It was also possible to include a larger amount of vegetation in still images than in real-time models, due to graphics and processing limitations (Lovett et al. 2009). This made stills more appropriate for visualising and comparing landscape-scale change, whereas the ability to move up to and through a Miscanthus plantation in a real-time model gave a more immediate impression of the crop's size and density of planting. The still images had further benefits in terms of the higher level of feature detail that could be incorporated, and were easy to include in Powerpoint ${ }^{\circledR}$ slides alongside maps that depicted the overall landscape setting (or change), as well as the viewpoint shown in the 3D visualisation. Linking such slides through transitions, and being able to switch back and forward between them as necessary, provided an efficient means of communicating different scenarios or planting options in meetings, though as noted above there were a few reservations expressed as to whether such visualisations gave people a sufficiently full impression of the crops.

\section{Conclusions}


It is apparent from the work undertaken here that public awareness and understanding of renewable energy and biomass crops has improved in recent years. Most members of the public were able to correctly differentiate between renewable and nonrenewable fuel sources, and a majority recognised biomass as a renewable fuel. However, the relatively small acreage and quite widely scattered distribution of biomass crops currently in the ground was reflected in the survey finding that only a relatively small percentage of people had direct experience of them. Nevertheless, based on the photographs and computer generated images of the crops presented to people during this study, most thought that these crops would fit into the local landscape 'very well' or 'reasonably well'.

There were a few, varied, concerns about either crop raised by either the questionnaire or focus group meetings. The issues noted reflected those raised by other participants contributing to the development of the Sustainability Appraisal framework that is part of the overall RELU-Biomass study. The most commonly expressed concerns related to loss of view and change to the landscape, increased lorry movements, and the 'food versus fuel' land-take issue, although none of these were overwhelmingly strongly stated. However, the contrast between the general acceptance of the crops in the landscape as shown in the questionnaire results, and the concerns expressed by the focus group participants, is worthy of further investigation. The sole benefit expressed within the focus groups was that in some circumstances, the new crops might improve diversity within the landscape. With these results noted, it is interesting that within the questionnaire survey 'landscape impact' received the lowest score of nine factors which could be taken into account when choosing how electricity should be produced in Britain in the future. It would be interesting to 
evaluate whether attitudes would change if biomass crops came to dominate the landscape in some areas.

The photographs and visualisations used in the study helped provide a focal point in meetings and were valuable for illustrating different scenarios or land management options. While there was a slight general preference for a 'patchwork' crop pattern to increase landscape diversity, and wide margins to offset visual intrusion and enhance biodiversity, these views were expressed by only a small number of participants and so cannot be regarded as statistically meaningful. In addition, the research design did not allow us to ascertain whether any of the visualisations used - photographs, static computer-generated images or real-time models - were really able to convey the true nature of the crops to people who had not seen them first-hand. This question of validity is becoming an increasingly important focus of research in many applications of visual simulation techniques, and urgently deserves more attention particularly in a rural context.

A significant next step in this field would be to undertake a further study with a sample of people who have no experience of either crop studied here, exposing them to the various visual media this study has produced as well as in situ experience of the crop both close-up and within a wider landscape context. As well as gathering responses to the crop, it should be assessed as to what degree participants' experience of the real vegetation is matched by their expectations from the visualisations. This would allow us to obtain more informed views of the crops' potential acceptability within the landscape as well as providing useful information on the validation of these types of visualisations as environmental surrogates.

Given the limitations previously indicated, and based on the findings obtained, it appears unlikely that wide-scale planting of biomass crops will give rise to 
substantial public concerns regarding visual impacts on the landscape. However, one of the most striking findings from the public survey was the reduction in support for the crops when faced with the prospect of attendant infrastructure. This supports previous observations that it is the infrastructure associated with the crops, rather than the crops per se, that is likely to attract more public concern. Agencies tasked with expanding the market for biomass crops are likely to find most support from communities for small scale schemes that have less prominent power generation infrastructure and bring direct benefit to the local area.

Acknowledgements: This research forms part of the RELU-Biomass project (http://www.relubiomass.org.uk) which was funded by the Rural Economy and Land Use Programme (RELU) of ESRC, BBSRC and NERC to provide a holistic assessment of the potential impacts of increasing rural land use under energy crops. RELU-Biomass was led by Rothamsted Research and also involved partners at the Centre for Ecology \& Hydrology, University of Exeter and The Game and Wildlife Conservation Trust. We are very grateful to all of those involved for their time and contribution to this study. Particular thanks are due to Jenny Morley, William Ashley-Cantello, Alicia Gailliez, Sarah Gregg, Alex Jones and Marie Prebble for their contributions to the implementation of the questionnaire survey. We greatly appreciated their hard work, perseverance and cheerfulness during the very wet summer of 2007. Thanks are also due to Gilla Sunnenberg who compiled the GIS data on which the computer-generated visualisations were based.

Appleton, J. 1996. The Experience of Landscape (Revised Edition). Chichester: Wiley.

BBC, 2007. Wheat prices reach record level. $24^{\text {th }}$ August. http://news.bbc.co.uk/1/hi/business/6962211.stm [Accessed 10/8/2010] 
Bishop, I. and Lange, E., (eds.) 2005. Visualisation in Landscape and Environmental Planning. London: Taylor \& Francis.

Daniel, T.C. and Meitner, M.M., 2001. Representational validity of landscape visualizations: The effects of graphical realism on perceived scenic beauty of forest vistas. Journal of Environmental Psychology, 21 (1), 61-72

Defra, 2004. Growing Short Rotation Coppice: Best Practice Guidelines for Applicants to Defra's Energy Crops Scheme. London: Department for Environment, Food and Rural Affairs.

Defra, 2007. Planting and Growing Miscanthus: Best Practice Guidelines for Applicants to Defra's Energy Crops Scheme. London: Department for Environment, Food and Rural Affairs.

Defra, 2009. Protecting our Water, Soil and Air; A Code of Good Agricultural Practice for farmers, growers and land managers.

http://www.defra.gov.uk/foodfarm/landmanage/cogap/documents/cogap090202.pdf [Accessed 10/8/2010]

Defra, DTI and DfT 2007. UK Biomass Strategy. London: Department for Environment, Food and Rural Affairs.

Devine-Wright, P., 2007. Reconsidering public attitudes and public acceptance of renewable energy technologies: a critical review. Manchester: School of Environment 
and Development, University of Manchester. Available at http://www.sed.manchester.ac.uk/research/beyond_nimbyism/

Devine-Wright, P., 2009. Rethinking NIMBYism: The Role of Place Attachemtn and Place Identity in Explaining Place-Protective Action. Journal of Community and Applied Social Psychology, 19, 426-441

Dockerty, T. L.; Lovett, A. A. and Morley, J., 2008. Assessing public attitudes to biomass crops as a renewable energy source: Results of a public questionnaire survey undertaken as part of the RELU Biomass project. University of East Anglia, May 2008.

DTI, 2003a. Attitudes and Knowledge of Renewable Energy amongst the General Public - Report of Findings, London: Taylor Nelson Sofres. Prepared for Central Office of Information.

DTI, 2003b. Attitudes to Renewable Energy. Final Report. London: Department of Trade and Industry. Prepared for COI Communications.

Dwyer, J. F., Schroeder, H. W. and Gobster, P. H., 1991. The significance of urban trees and forests: toward a deeper understanding of values. Journal of Arboriculture 17 (10), 276-284.

English Heritage, 2006. Biomass Energy and the Historic Environment. London: English Heritage. 
Forestry Commission, 1992. Lowland Landscape Design Guidelines. Stirling:

Forestry Commission.

Forestry Commission, 2001. Short Rotation Coppice in the Landscape. Stirling:

Forestry Commission. http://www.forestry.gov.uk/PDF/fcgn2.pdf/\$FILE/fcgn2.pdf

[Accessed 10/8/2010]

Hall, 2006. National Labour Force Survey 2005. London: Office for National Statistics.

Haughton, A. J., Bond, A. J., Lovett, A. A., Dockerty, T. L., Sünnenberg, G., Clark, S. J., Bohan, D. A., Sage, R. B., Mallott, M. D., Mallott, V. E., Cunningham, M. D., Riche, A. B., Shield, I. F., Finch, J. W., Turner, M. M., and Karp, A., 2009. A novel, integrated approach to assessing social, economic and environmental implications of changing rural land-use: a case study of perennial biomass crops. Journal of Applied Ecology, 46 (2), 315-322.

HM Government 2009. The UK Renewable Energy Strategy. Surrey: Office of Public Information.

http://www.decc.gov.uk/en/content/cms/what_we_do/uk_supply/energy_mix/renewab le/res/res.aspx [Accessed 10/8/2010]

Hull IV, R.B. and Stewart, W. P., 1992. Validity of photo-based scenic beauty judgments. Journal of Environmental Psychology 12 (2), 101-114 
Johnston, D., 2010. Introduction to a Symposium on the 2007-8 World Food Crisis. Journal of Agrarian Change, 10 (1), 69-71.

Lovett, A. A., Appleton, K.J., Paar, P. and Ross, L., 2009a. Evaluating real-time landscape visualisation techniques for public communication of energy crop planting scenarios. In: Lin, H. and Batty M., eds. Virtual Geographic Environments. Beijing, China: Science Press. 103-116.

Lovett, A. A., Sünnenberg, G., Richter, G. M., Dailey, A. G., Riche, A. B., and Karp, A., 2009b. Land use implications of increased biomass production identified by GISbased suitability and yield mapping for Miscanthus in England. Bioenergy Research, $2(1-2), 17-28$.

Jude, S. R., Jones, A. P., Andrews, J. E. and Bateman, I. J., 2006. Visualisation for participatory coastal zone management: a case study of the Norfolk Coast, England. Journal of Coastal Research, 22, 1527-1538.

Miller, D., Morrice, J., Coleby, A. and Messager, P., 2008. Visualization techniques to support planning of renewable energy developments. In: Lovett, A. and Appleton, K., eds. GIS for Environmental Decision-Making. Boca Raton, FL: CRC Press, 227239.

Monbiot, G., 2007. If we want to save the planet, we need a five-year freeze on biofuels. The Guardian, 27 March 
http://www.guardian.co.uk/commentisfree/2007/mar/27/comment.food [Accessed $10 / 8 / 2010]$

MORI, 2004. Attitudes to Renewable Energy in Devon: Summary Report, Research Study Conducted for Regen SW. London: MORI Social Research Institute.

MORI, 2005. Views of the British Nation Topline Findings (21/11/05). London: MORI Social Research Institute.

Natural England, 2007. Energy Crops Scheme-Establishment Grants Handbook. Sheffield, UK: Natural England.

Palmer, J.F. and Hoffman, R.E., 2001. Rating reliability and representation validity in scenic landscape assessments. Landscape and Urban Planning, 54 (1-4), 149-161.

Poortinga, W., Pidgeon, N. F., and Lorenzoni, I., 2006. Public Perceptions of Nuclear Power, Climate Change and Energy Options in Britain: Summary Findings of a Survey Conducted during October and November 2005. Technical Report, Understanding Risk Working Paper 06-02, Centre for Environmental Risk. Norwich: University of East Anglia.

Rowe, R., Street, N., and Taylor, G., 2009. Identifying potential environmental impacts of large-scale deployment of dedicated energy crops in the UK. Renewable and Sustainable Energy Reviews, 13 (1), 271-290. 
Royal Commission on Environmental Pollution, 2004. Biomass as a Renewable Energy Resource. London: Royal Commission on Environmental Pollution.

Rural Payments Agency and Defra, 2007. Management of Habitats and Landscape Features: Guidance for Cross Compliance in England.

http://www.crosscompliance.org.uk/cms/assets/Uploads/PDFs/ManagementHabitatsL andscapeFeatGuideXCompEngland.pdf [Accessed 10/8/2010]

Stewart, T.R., Middleton, P., Downton, M. and Ely, D., 1984. Judgments of photographs vs. field observations in studies of perception and judgment of the visual environment. Journal of Environmental Psychology, 4 (4), 283-302.

Swanwick, C., Hanley, N. and Termansen, M., 2007. Scoping Study on Agricultural Landscape Valuation: Final report to Defra.

http://www.defra.gov.uk/evidence/economics/foodfarm/reports/agrlandval/Mainrep.p df [Accessed 10/8/2010]

UN-Energy 2007. Sustainable Bioenergy: A Framework for Decision Makers. New York: United Nations.

Upham, P. and Shackley, S., 2006. Stakeholder opinion of a proposed 21.5 MWe biomass gasifier in Winkleigh, Devon: Implications for bioenergy planning and policy, Journal of Environmental Policy and Planning, 8, 45-66. 
Upreti, B. R., 2004. Conflict over biomass energy development in the United Kingdom: some observations and lessons from England and Wales, Energy Policy, $32,785-800$.

Wergles, N. and Muhar A., 2009. The role of computer visualization in the communication of urban design - a comparison of viewer responses to visualizations versus on-site visits. Landscape and Urban Planning, 91, 171-182.

Wildlife and Countryside Link 2007. Bioenergy in the UK: Turning Green Promises into Environmental Reality.

http://wcl.org.uk/downloads/2007/Bioenergy_in_the_UK_Link_paper_final.pdf

[Accessed 10/8/2010] 
Table 1: Scenarios used in focus groups and interviews

\begin{tabular}{|l|l|}
\hline East Midlands & South West \\
\hline 1: Total Land Cover: 50/50 SRC/Miscanthus & 1: Total Land Cover: Monocrop Miscanthus \\
\hline a) "Suitable" 72,000 Ha of SRC and Miscanthus & a) "Suitable" 43,000 Ha of Miscanthus \\
\hline b) "Minimum" 18,000 Ha of SRC and Miscanthus & b) "Minimum" 18,000 Ha of Miscanthus \\
\hline c) "Extreme" 200,000 Ha of SRC and Miscanthus & c) "Extreme" 130,000 Ha of Miscanthus \\
\hline 2: Biomass End Use \\
\hline a) Small-scale CHP \\
\hline b) Large-scale co-firing \\
\hline c) Dedicated Biomass \\
\hline $\begin{array}{l}\text { 3: Crop Management/Field Distribution Pattern: } \\
\text { (East Midlands: no mixing of SRC/Miscanthus on any individual farm) }\end{array}$ \\
\hline a) Heavily aggregated \\
\hline b) Realistic scenario (based on current pattern) \\
\hline c) Evenly spread across the landscape \\
\hline 4: Crop Management: Headland Size \\
\hline a) 4m field margins \\
\hline b) 10m field margins
\end{tabular}


Table 2: Survey questions and available responses

Q1: These are all sources of electricity generation in Britain. To what extent do you approve of each of these sources being used for electricity production?

\begin{tabular}{|c|c|c|c|c|c|c|c|}
\hline $\begin{array}{l}\text { Biomass } \\
\text { (e.g. wood, energy crops, } \\
\text { straw, chicken litter) }\end{array}$ & Coa & $\begin{array}{l}\text { Natural } \\
\text { Gas }\end{array}$ & $\begin{array}{l}\text { Hydroelectric } \\
\text { Power (generated } \\
\text { from flowing water }\end{array}$ & Oil & $\begin{array}{l}\text { Sun/Solar } \\
\text { Power }\end{array}$ & $\begin{array}{l}\text { Tidal Power } \\
\text { (generated from the } \\
\text { movement of the } \\
\text { tides) }\end{array}$ & $\begin{array}{l}\text { Wind } \\
\text { Power }\end{array}$ \\
\hline & & $\begin{array}{c}\text { Slight } \\
\text { Approval }\end{array}$ & $\begin{array}{c}\text { No } \\
\text { Opinion }\end{array}$ & $\begin{array}{c}\text { Slight } \\
\text { Opposition }\end{array}$ & $\begin{array}{c}\text { Strong } \\
\text { Opposition }\end{array}$ & $\begin{array}{l}\text { Don't } \\
\text { Know }\end{array}$ & \\
\hline
\end{tabular}

Q2: Renewable energy comes from sources that are regenerated naturally more quickly than they are being consumed. Which of these possible sources of electricity would you regard as renewable?

\begin{tabular}{|c|c|c|c|c|c|c|c|c|}
\hline $\begin{array}{l}\text { Biomass } \\
\text { (e.g. Wood, energy crops, } \\
\text { straw, chicken litter) }\end{array}$ & Coal & $\begin{array}{l}\text { Natural } \\
\text { Gas }\end{array}$ & $\begin{array}{l}\text { Hydr } \\
\text { Pow } \\
\text { from flc }\end{array}$ & $\begin{array}{l}\text { lectric } \\
\text { (generated } \\
\text { ng water }\end{array}$ & Oil & $\begin{array}{l}\text { Sun/Solar } \\
\text { Power }\end{array}$ & $\begin{array}{l}\text { Tidal Power } \\
\text { (generated from the } \\
\text { movement of the } \\
\text { tides) }\end{array}$ & $\begin{array}{l}\text { Wind } \\
\text { Power }\end{array}$ \\
\hline & & \multicolumn{2}{|c|}{ Renewable } & $\begin{array}{c}\text { Non- } \\
\text { Renewable }\end{array}$ & & $\begin{array}{l}\text { n't } \\
\text { ow }\end{array}$ & & \\
\hline
\end{tabular}

Q3: Government, industry and environmental groups are currently thinking about how Britain should generate electricity in the future. In your opinion, which THREE of these factors, are the most important for deciding which methods of electricity production should be used in Britain in the future? Please read out the letters which apply to your $1^{\text {st }}, 2^{\text {nd }}$ and $3^{\text {rd }}$ choices.

\begin{tabular}{|l|l|l|l|}
\hline A & Cost to the consumer & G & Level of pollution \\
\hline B & Effects on the economy & H & Reliability of supplies \\
\hline C & Effects on the environment & I & Safety \\
\hline D & Effects on human health & J & None of these \\
\hline E & Effects on the landscape & K & Don't know \\
\hline F & $\begin{array}{l}\text { Helping to prevent climate } \\
\text { change }\end{array}$ & & \\
\hline
\end{tabular}

Q4: Here are some pictures of two new energy crops - Short Rotation Coppice and Miscanthus. These can be cut and processed into fuel pellets and used for heat or electricity generation. They are now being grown in several parts of Britain. Have you noticed either of these crops being grown around here?

\begin{tabular}{|l|l|l|l|}
\hline Short Rotation Coppice & Yes & No & Don't know \\
\hline Miscanthus & Yes & No & Don't know \\
\hline
\end{tabular}

Q5: Here are some photos of Short Rotation Coppice in a landscape setting. To what extent do you think Short Rotation Coppice would fit into the landscape in this area?

Q6: Here are some photos of Miscanthus in a landscape setting. To what extent do you think Miscanthus would fit into the landscape in this area?

\begin{tabular}{|c|c|c|c|c|c|}
\hline $\begin{array}{c}\text { Very } \\
\text { Well }\end{array}$ & $\begin{array}{c}\text { Reasonably } \\
\text { Well }\end{array}$ & $\begin{array}{c}\text { No } \\
\text { Concerns }\end{array}$ & $\begin{array}{c}\text { Some } \\
\text { Concerns }\end{array}$ & $\begin{array}{c}\text { Major } \\
\text { Concerns }\end{array}$ & $\begin{array}{c}\text { Don't } \\
\text { Know }\end{array}$ \\
\hline
\end{tabular}

\begin{tabular}{|l|l|l|}
\hline a) within the view from your home & $\begin{array}{l}\text { d) more than } 5 \text { miles away but less than } \\
10 \text { miles from your home }\end{array}$ \\
\hline b) on the outskirts of your town or village & & e) further away than 10 miles \\
\hline $\begin{array}{l}\text { c) more than 1 mile away but less than 5 } \\
\text { miles from your home }\end{array}$ & f) should not be grown at all \\
\hline
\end{tabular}

Q8: Do you have a favourite local walk in the countryside? Yes / No if yes -

Q9: How close to your favourite walk would you mind these crops being grown? (9a) SRC (9b) MISCANTHUS

\begin{tabular}{|l|}
\hline a) alongside the footpath \\
\hline b) within the view you can see \\
\hline c) should not be seen at all \\
\hline
\end{tabular}

Q10: This is a biomass power station [Figure 6]. To make it cost effective to produce electricity from biomass crops, the crops can only be transported up to 25 miles - so the power station would need to be situated within the area where the crops are grown. How close to your home would you mind if these crops were grown? (10b) SRC (10a) MISCANTHUS

\begin{tabular}{|l|l|l|}
\hline a) within the view from your home & $\begin{array}{l}\text { d) more than } 5 \text { miles away but less than } \\
10 \text { miles from your home }\end{array}$ \\
\hline b) on the outskirts of your town or village & & e) further away than 10 miles \\
\hline $\begin{array}{l}\text { c) more than 1 mile away but less than } 5 \\
\text { miles from your home }\end{array}$ & f) should not be grown at all \\
\hline
\end{tabular}


Table 3: Responses to Q1 (see Table 2):

\begin{tabular}{|l|l|l|l|l|l|l|}
\hline & $\begin{array}{l}\text { Strong } \\
\text { approval }\end{array}$ & $\begin{array}{l}\text { Slight } \\
\text { approval }\end{array}$ & $\begin{array}{l}\text { No } \\
\text { opinion }\end{array}$ & $\begin{array}{l}\text { Slight } \\
\text { opposition }\end{array}$ & $\begin{array}{l}\text { Strong } \\
\text { opposition }\end{array}$ & $\begin{array}{l}\text { Don't } \\
\text { know }\end{array}$ \\
\hline A) Biomass & $38.0(18)$ & $28.0(36)$ & $9.2(17)$ & $7.2(6)$ & $5.9(2)$ & $11.7(19)$ \\
\hline B) Coal & $12.7(7)$ & $27.8(31)$ & $8.2(24)$ & $27.2(25)$ & $22.3(8)$ & $1.8(3)$ \\
\hline C) Natural Gas & $22.9(10)$ & $35.2(45)$ & $12.7(21)$ & $20.2(14)$ & $7.2(4)$ & $1.8(3)$ \\
\hline D) Hydro Power & $77.3(36)$ & $13.7(40)$ & $2.2(11)$ & $3.1(2)$ & $1.6(1)$ & $2.0(10)$ \\
\hline E) Nuclear & $19.4(9)$ & $17.0(27)$ & $7.4(22)$ & $15.1(20)$ & $36.8(17)$ & $4.3(7)$ \\
\hline F) Oil & $7.0(6)$ & $20.7(33)$ & $11.2(22)$ & $32.3(25)$ & $26.6(8)$ & $2.2(4)$ \\
\hline G) Sun/Solar & $80.4(55)$ & $13.5(32)$ & $2.4(6)$ & $2.0(2)$ & $0.8(1)$ & $0.6(2)$ \\
\hline H) Tidal Power & $75.3(\mathrm{n} / \mathrm{a})$ & $16.8(\mathrm{n} / \mathrm{a})$ & $3.5(\mathrm{n} / \mathrm{a})$ & $1.8(\mathrm{n} / \mathrm{a})$ & $1.0(\mathrm{n} / \mathrm{a})$ & $1.6(\mathrm{n} / \mathrm{a})$ \\
\hline I) Wind Power & $69.1(50)$ & $18.6(31)$ & $3.1(8)$ & $3.9(5)$ & $4.3(2)$ & $1.0(2)$ \\
\hline
\end{tabular}

Note: Values are percentages. Figures in brackets are from the 2005 UEA/MORI survey. 
Table 4: Responses to Q3 (see Table 2)

\begin{tabular}{|l|l|l|l|l|l|l|l|}
\hline Factor & $\begin{array}{l}\mathbf{1}^{\text {st }} \\
\text { choice }\end{array}$ & $\begin{array}{l}\mathbf{2}^{\text {nd }} \\
\text { choice }\end{array}$ & $\begin{array}{l}\mathbf{3}^{\text {rd }} \\
\text { choice }\end{array}$ & $\begin{array}{l}\text { Total } \\
\text { mentions }\end{array}$ & $\begin{array}{l}\text { \% of all } \\
\text { mentions }\end{array}$ & Rank & $\begin{array}{l}\text { UEA/MORI } \\
\text { survey rank }\end{array}$ \\
\hline Cost to the consumer & 79 & 29 & 55 & 163 & 11.1 & 4 & 5 \\
\hline Effects on the economy & 14 & 27 & 28 & 69 & 4.7 & & \\
\hline Effects on the environment & 164 & 114 & 69 & 347 & 23.6 & 1 & 2 \\
\hline Effects on human health & 71 & 114 & 75 & 260 & 17.7 & 2 & 1 \\
\hline Effects on the landscape & 4 & 17 & 33 & 54 & 3.7 & & \\
\hline $\begin{array}{l}\text { Helping to prevent climate } \\
\text { change }\end{array}$ & 60 & 58 & 69 & 187 & 12.7 & 3 & 3 \\
\hline Level of pollution & 30 & 50 & 79 & 159 & 10.8 & 5 & 4 \\
\hline Reliability of supplies & 29 & 38 & 34 & 101 & 6.9 & 7 & 7 \\
\hline Safety & 34 & 36 & 40 & 110 & 7.5 & 6 & 6 \\
\hline None of these & 3 & 1 & 1 & 5 & 0.3 & & \\
\hline Don't know & 1 & 1 & 0 & 2 & 0.1 & & \\
\hline Missing Values & 1 & 5 & 7 & 13 & 0.9 & & \\
\hline
\end{tabular}

Note: Values are counts.

Table 5: Responses to Q5 and Q6 (see Table 2)

\begin{tabular}{|l|l|l|l|l|l|l|}
\hline & $\begin{array}{l}\text { Very } \\
\text { well }\end{array}$ & $\begin{array}{l}\text { Reasonably } \\
\text { well }\end{array}$ & $\begin{array}{l}\text { No } \\
\text { concerns }\end{array}$ & $\begin{array}{l}\text { Some } \\
\text { concerns }\end{array}$ & $\begin{array}{l}\text { Major } \\
\text { concerns }\end{array}$ & $\begin{array}{l}\text { Don't } \\
\text { know }\end{array}$ \\
\hline SRC & 55.5 & 31.2 & 5.1 & 4.5 & 3.1 & 0.6 \\
\hline Miscanthus & 42.2 & 32.9 & 5.9 & 15.5 & 2.9 & 0.6 \\
\hline
\end{tabular}

Note: Values are percentages. 
Table 6: Concerns and benefits raised in interview and focus group discussions

\begin{tabular}{|c|c|c|}
\hline Concern & $\begin{array}{l}\text { Number of } \\
\text { mentions }\end{array}$ & $\begin{array}{l}\text { SA objective } \\
\text { (Table 8) }\end{array}$ \\
\hline You would not want it near footpaths or houses (obscures the view) & 7 & $\mathrm{D} / \mathrm{H} / \mathrm{R}$ \\
\hline Conspicuous in landscape / 'Alien' appearance & 4 & $\mathrm{H}$ \\
\hline Increased number of lorry movements & 4 & $\mathrm{~N}$ \\
\hline $\begin{array}{l}\text { Loss of best/most versatile agricultural land and its use for food production (Food } \\
\text { v Fuel) }\end{array}$ & 4 & $\mathrm{~S}$ \\
\hline $\begin{array}{l}\text { Local focus should be on utilising existing wood fuel through better woodland } \\
\text { management (no landscape change implications) }\end{array}$ & 4 & \\
\hline Soil depletion & 3 & $\mathrm{~L}$ \\
\hline $\begin{array}{l}\text { Instead of planting Miscanthus make use of biomass from other crops - why isn't } \\
\text { Somerset growing traditional willow? (for fuel) }\end{array}$ & 3 & \\
\hline No local energy production scheme & 2 & $\mathrm{~F}$ \\
\hline Wind blown crop debris (sharp leaves and stems) / Rustling noise from crop & 2 & \\
\hline Water runoff on roads/ in watercourses during harvest & 2 & $\mathrm{~J}$ \\
\hline Mud on roads during harvest & 2 & $\mathrm{~N}$ \\
\hline $\begin{array}{l}\text { Unsuitability of transport distance to nearest co-firing facility (For SW: Aberthaw, } \\
100 \text { miles) }\end{array}$ & 2 & $\mathrm{~N}$ \\
\hline Potential for roots to damage archaeological remains & 1 & A \\
\hline Potential for interference with Rights of Way & 1 & $\mathrm{D}$ \\
\hline $\begin{array}{l}\text { Miscanthus should not be planted in areas of high landscape sensitivity / value e.g. } \\
\text { some areas of National Parks and AONBs. }\end{array}$ & 1 & $\mathrm{H}$ \\
\hline Large-scale infrastructure associated with production & 1 & $\mathrm{H}$ \\
\hline Winter appearance looks like an abandoned crop & 1 & $\mathrm{H}$ \\
\hline Depletion of water tables & 1 & $\mathrm{~K}$ \\
\hline On poorer soils it may not produce the yields promised in trials & 1 & $\mathrm{~S}$ \\
\hline Impact of harvesting in Jan/Feb on birds that are using SRC for roosting/shelter. & 1 & $\mathrm{~B}$ \\
\hline \multicolumn{3}{|l|}{ Benefit } \\
\hline Enhances landscape diversity and appearance & 6 & $\mathrm{H}$ \\
\hline Could make a modest contribution to renewable energy & 2 & $\mathrm{~F}$ \\
\hline
\end{tabular}


Table 7: Responses to scenario elements from interview and focus group discussions

\begin{tabular}{|c|c|}
\hline Planting scenario & $\begin{array}{l}\text { Number of } \\
\text { mentions }\end{array}$ \\
\hline $\mathrm{C}$-dispersed & 3 \\
\hline Small fields/blocks would be best & 2 \\
\hline $\mathrm{A}-$ random & 2 \\
\hline $\mathrm{B}$ - concentrated & 0 \\
\hline \multicolumn{2}{|l|}{ Margins } \\
\hline $\mathrm{C}-10 \mathrm{~m}$ Margin & 4 \\
\hline A - No margin & 2 \\
\hline$B-4 m$ Margin & 1 \\
\hline \multicolumn{2}{|l|}{ End use } \\
\hline D - Small-scale Boilers & 3 \\
\hline $\mathrm{A}-\mathrm{Co}$-firing & 1 \\
\hline $\mathrm{C}-\mathrm{CHP}$ & 1 \\
\hline $\mathrm{B}$ - Dedicated biomass & 0 \\
\hline
\end{tabular}


Table 8: Objectives for Sustainability Appraisal of biomass planting identified in RELU-Biomass stakeholder meetings

\begin{tabular}{|l|}
\hline A Safeguard the historic environment \\
\hline B Protect and enhance biodiversity \\
\hline C Reduce greenhouse gas emissions \\
\hline D Improve public connection with the countryside \\
\hline E Enhance rural employment \\
\hline F Increase amount of energy produced and used locally \\
\hline G Reduce energy costs \\
\hline H Enhance local landscape character \\
\hline I Enhance rural quality of life \\
\hline J Improve water quality \\
\hline K Maintain water availability \\
\hline L Protect and improve soil resources \\
\hline M Improve air quality \\
\hline N Minimise additional vehicle movements \\
\hline O Maximise waste management opportunities \\
\hline P Increase the viability of local economies \\
\hline Q Enhance viability of farming \\
\hline R Maintain tourism resource \\
\hline S Maintain food security \\
\hline
\end{tabular}


Authors' note: if accepted for publication, large colour versions of the figures will be made available on a given web page

Figure 1: views of Miscanthus field in the South West in June and November

June

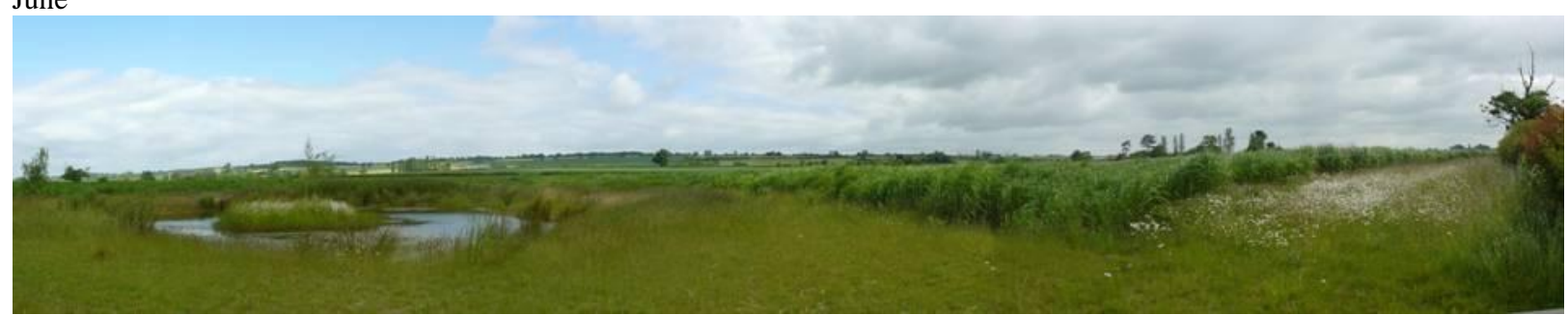


Figure 2: Computer-generated images used to represent different planting distributions

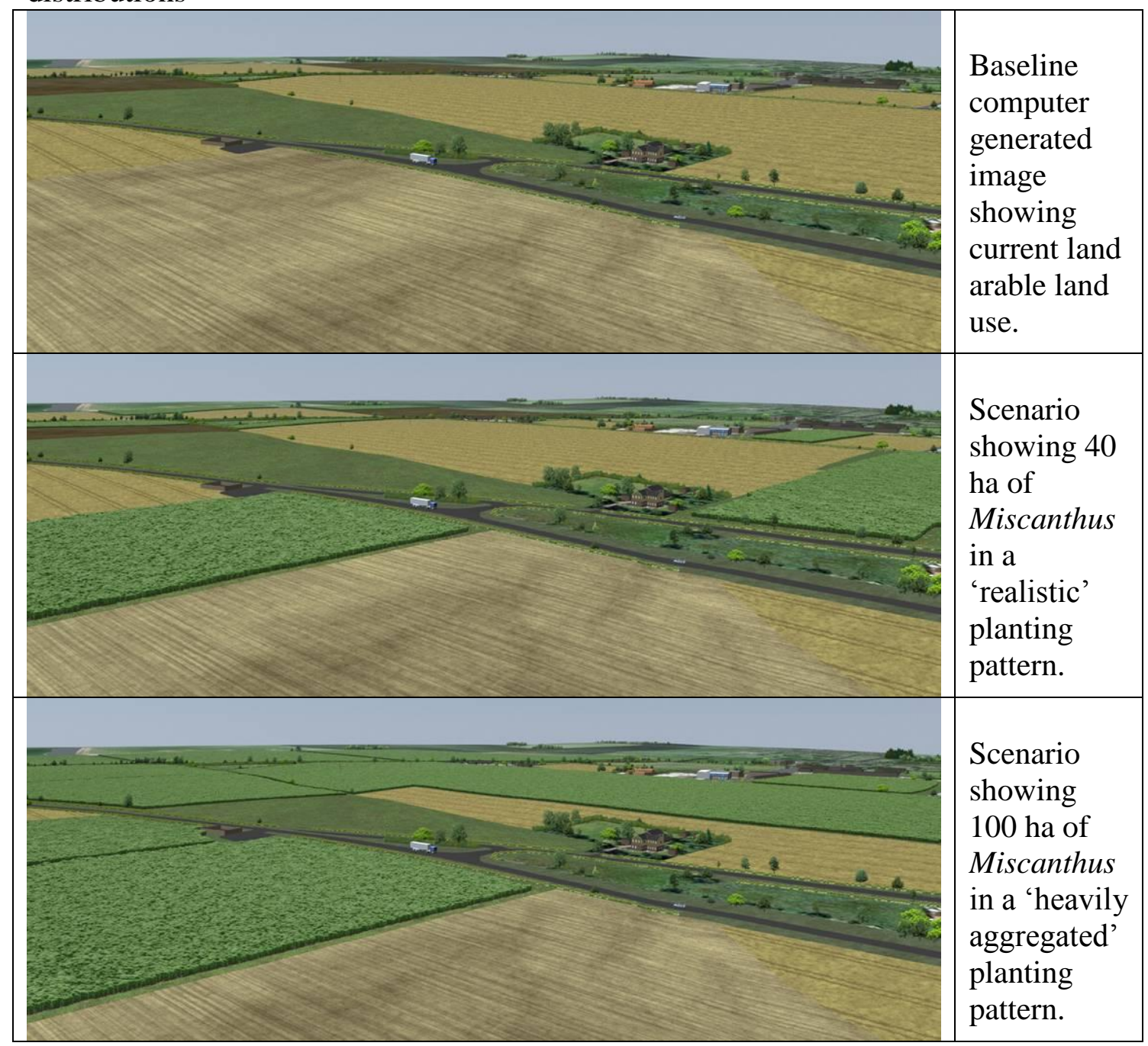


Figure 3: Computer-generated images of views along a public byway

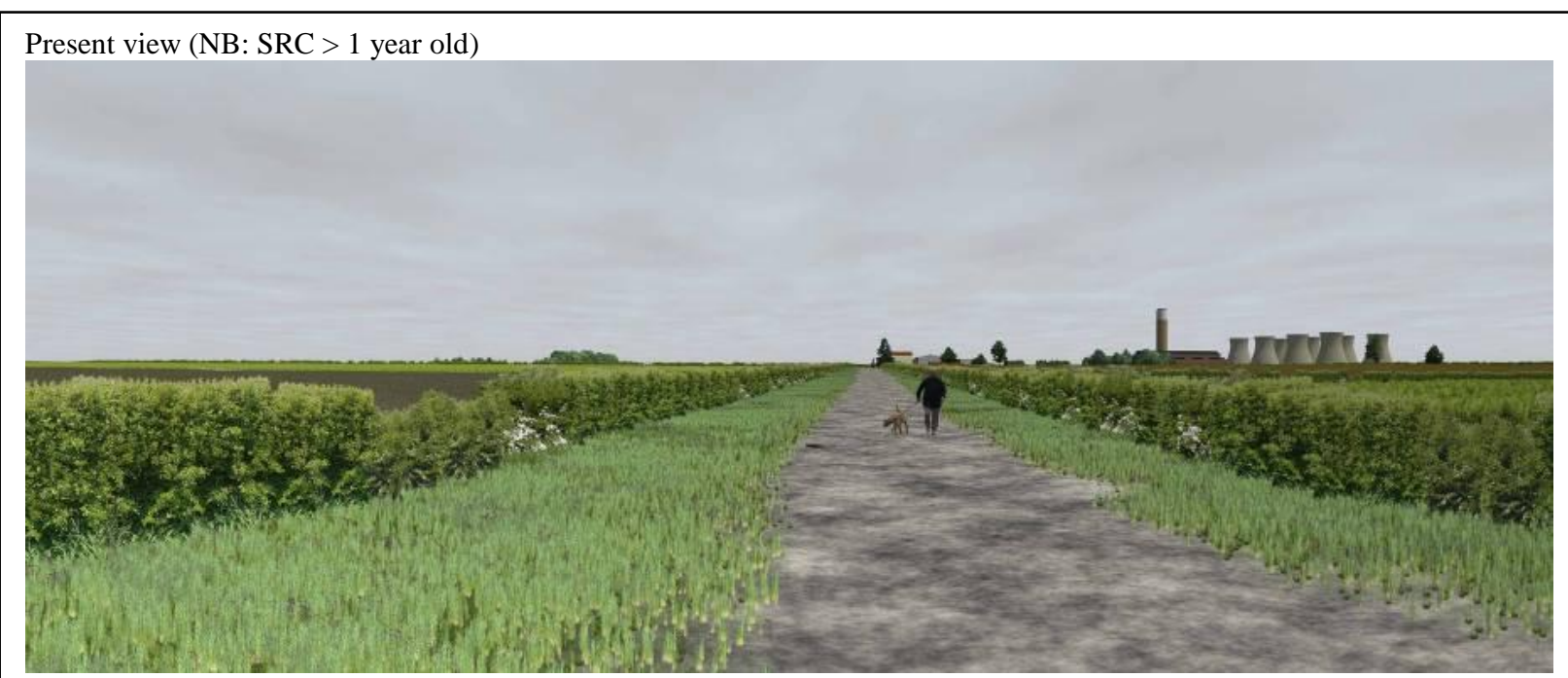

View with mature SRC and $10 \mathrm{~m}$ field margins

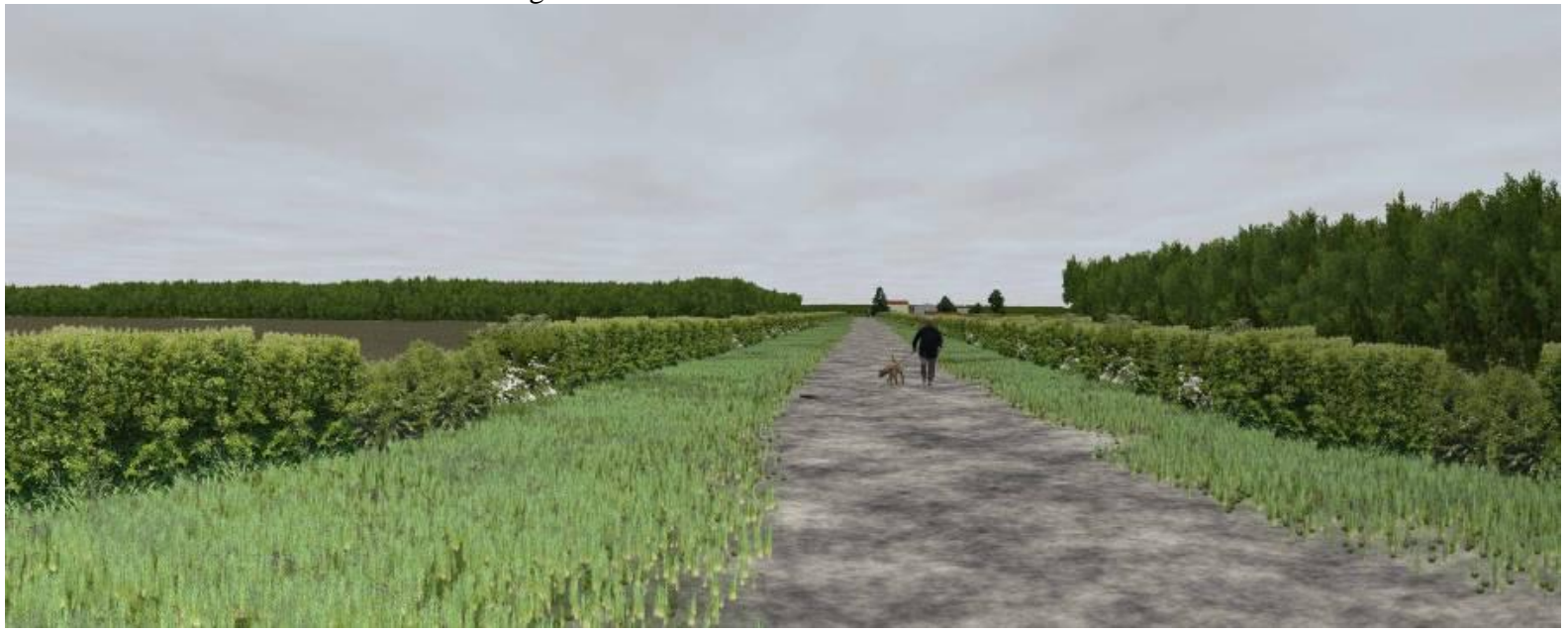

View with mature SRC and 4m field margins

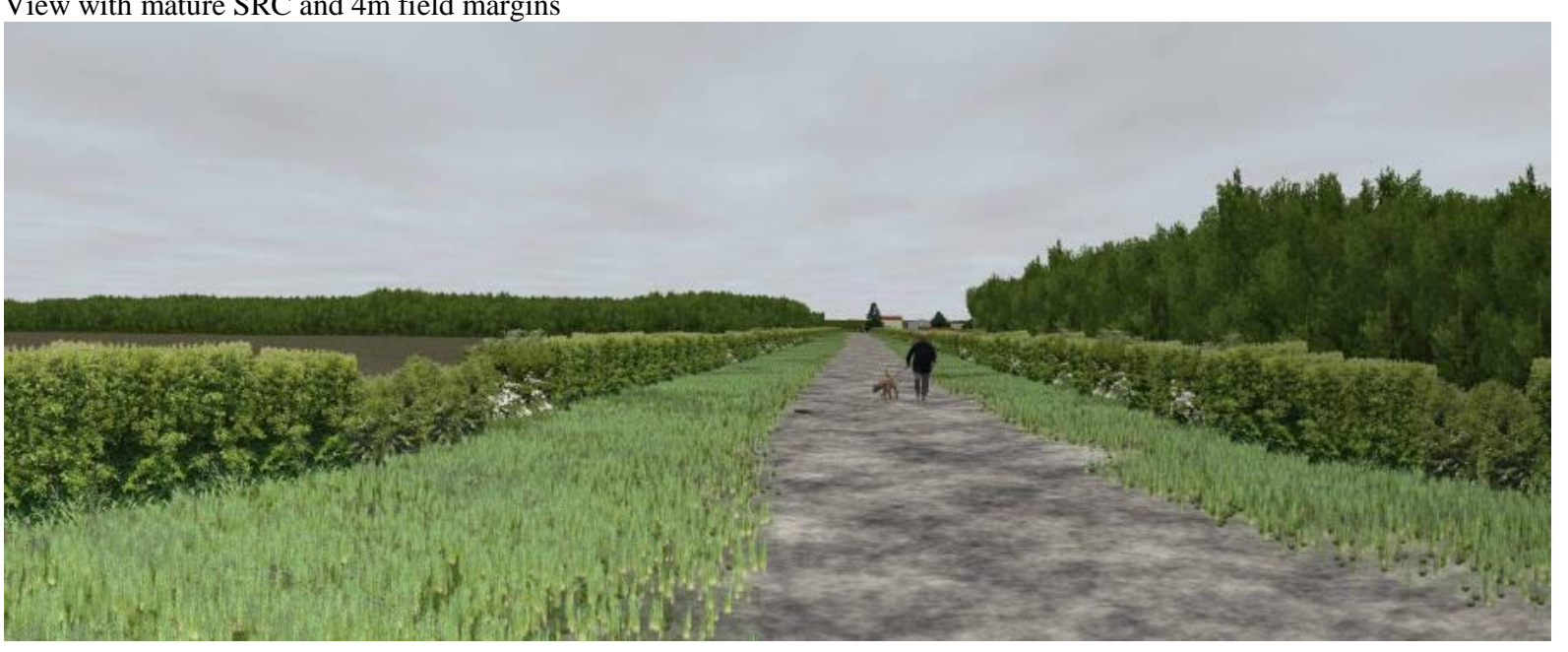


Figure 4: Example of information on land suitable for biomass crops compared with energy needs

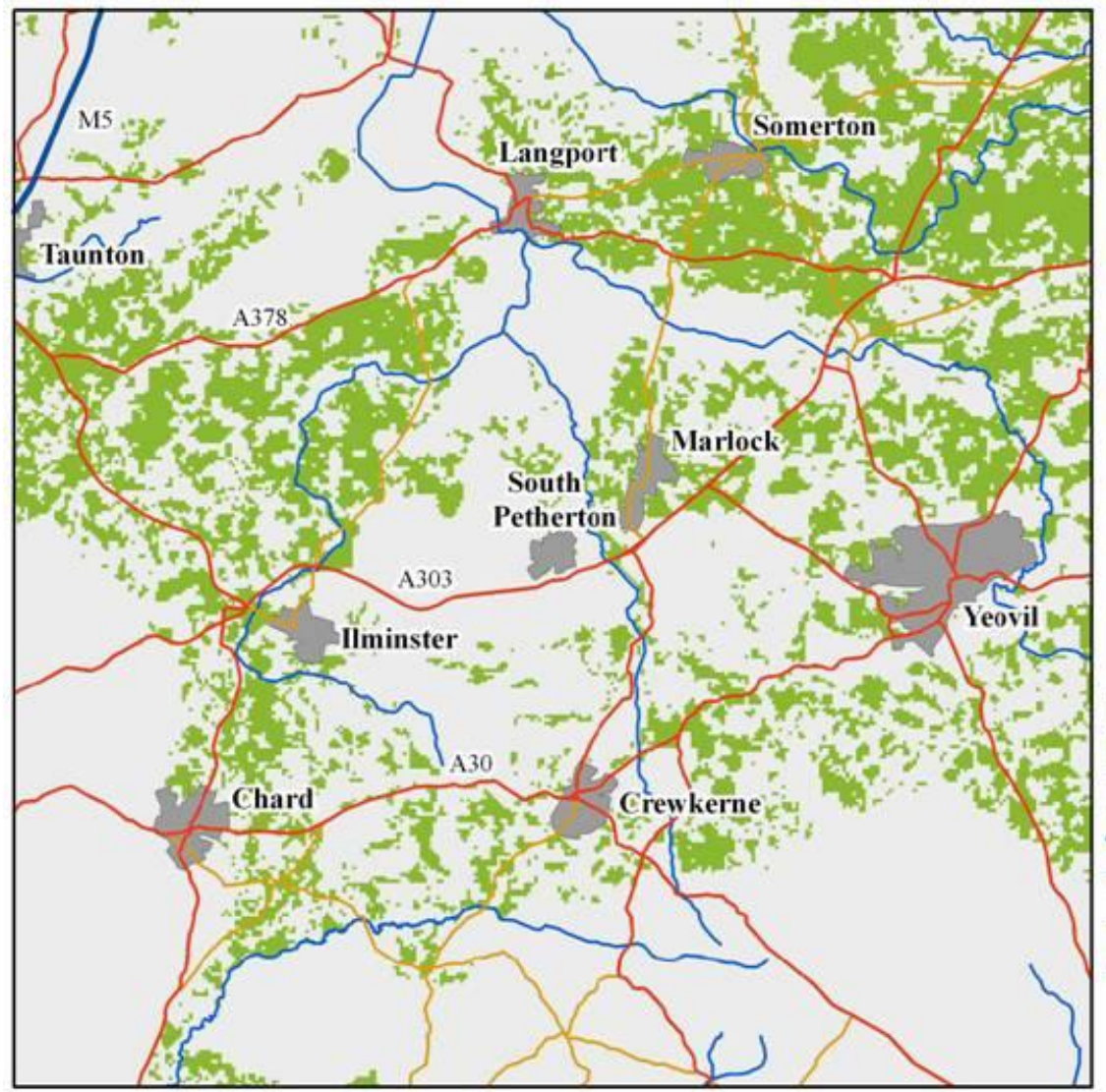

Other Land

Grade 3 or 4 Land meeting Constraints

Urban Areas

Motorway

A-Roads

B-Roads

Rivers

Implications for Ilminster:

Approximately 18,000 ha of potential land within 10 miles.

To provide combined heat and power for 2,100 households would need 2,000 ha of Miscanthus.

For heat alone $\sim 1,200$ ha of Miscanthus (but also requires boilers in individual houses).

\section{Implications for South Petherton:}

Approximately 24,000 ha of potential land within 10 miles.

To provide combined heat and power for 1,400 households would need $\sim$ 1,300 ha of Miscanthus.

For heat alone $\sim 750$ ha of Miscanthus (but also requires boilers in individual houses). 
Figure 5: Dedicated 40mw biomass power station

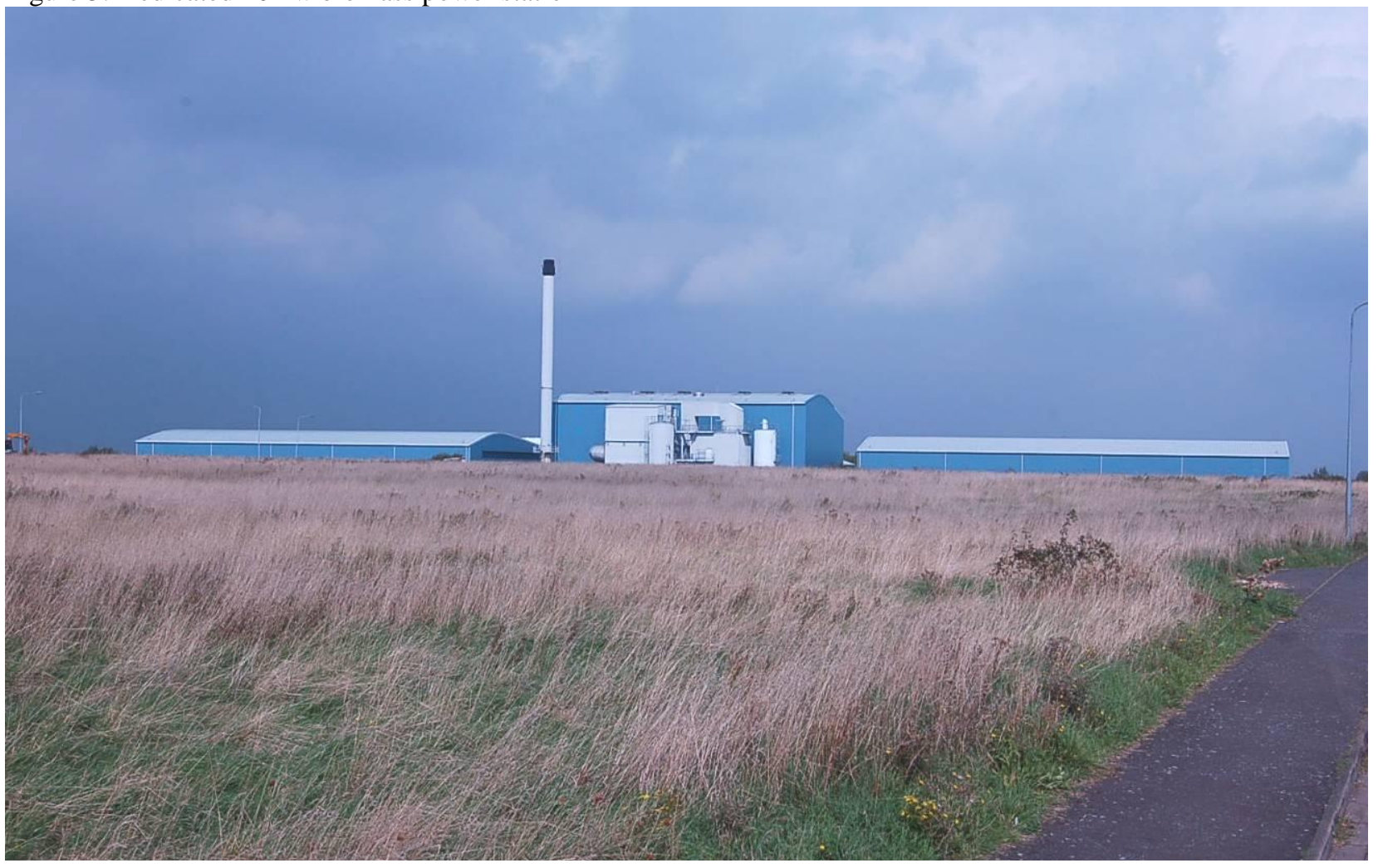


Figure 6: Changes in responses before and after presentation of power station infrastructure

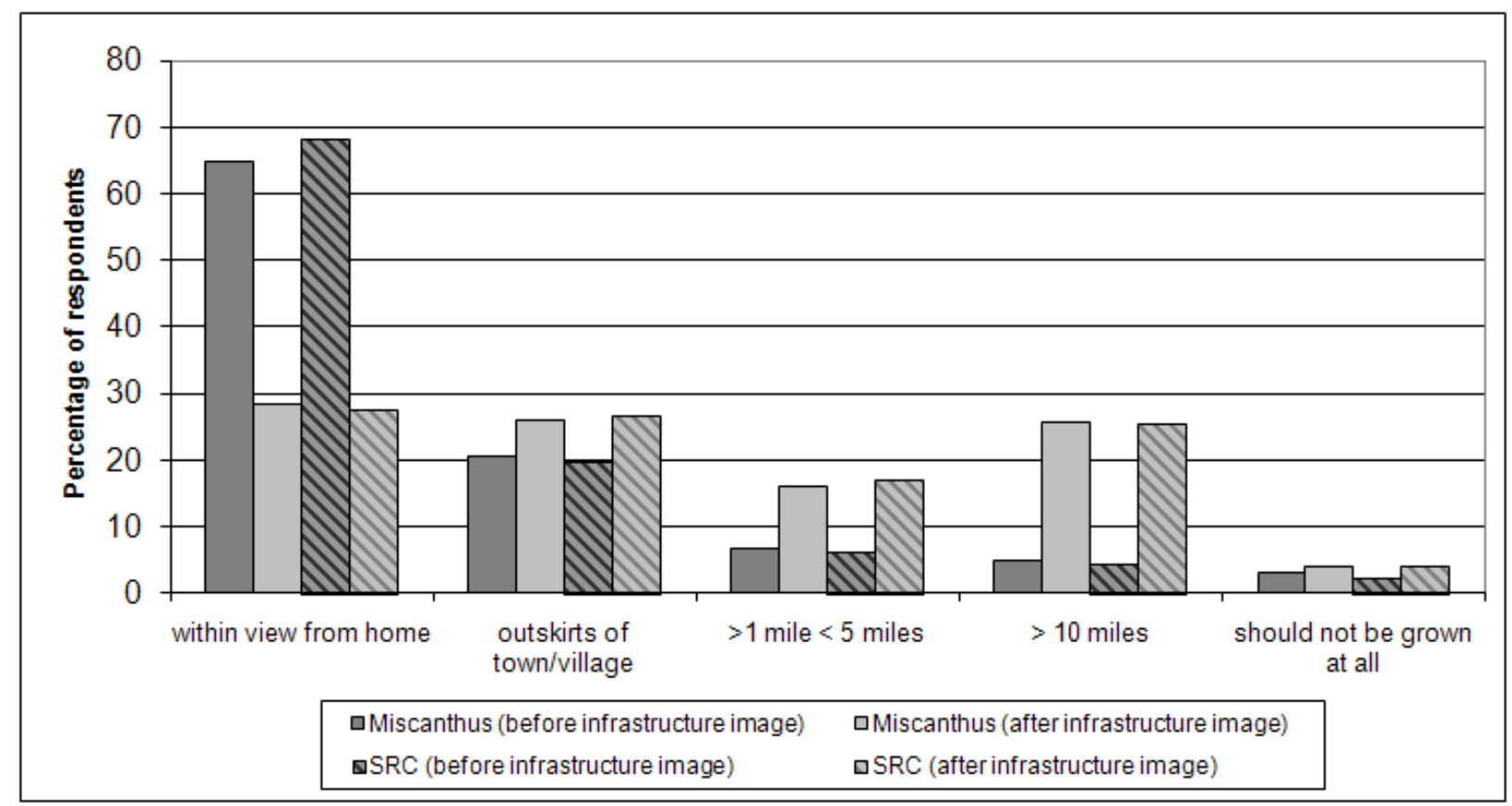

